Zbigniew Pietrzak

Uniwersytet Wrocławski, Wrocław

ORCID: 0000-0003-2458-1252

e-mail: zbigniew.pietrzak@uwr.edu.pl

\title{
○óżnorodności zasad: filozoficznych, matematycznych i empirycznych, leżących u podstaw nowożytnego przyrodoznawstwa
}

\section{Wstęp}

Można pokusić się o stwierdzenie, że intelektualne dzieje i dorobek kultury europejskiej (lub ogólniej - cywilizacji zachodniej) są zakorzenione ${ }^{1}$ w dwóch starożytnych dziełach - Biblii oraz Elementach Euklidesa. Jednakże te dwa dzieła są nieredukowalne względem siebie co do treści, przeznaczenia a także metody, wskutek skrajnie odmiennych źródeł w mniemaniu ich twórców i zwolenników - konstytuujących głoszoną wiedzę; źródeł sankcjonujących i uprawomocniających tę odmienność i świadczących także o odmiennej wizji świata. Efektem tego dualizmu jest swoisty pluralizm intelektualny (mentalny), ujawniający się w dziejach kultury europejskiej nawet w czasach, gdy w "oficjalnym obiegu" tolerowany był tylko jeden pogląd, jedna wykładnia rzeczywistości. Ta odmienność przyczyniła się do tego, że w europejskiej kulturze mog-

${ }^{1}$ Alfred N. Whitehead w książce Przygody idei, poszukując korzeni cywilizacji zachodniej, szczególnie w związku z wiedzą o człowieku, przywołuje Grecję i Palestynę, wymieniając także Egipt w kontekście wiedzy naukowej; por. Alfred N. Whitehead, Przygody idei, przeł. Marek Piwowarczyk (Warszawa: PWN, 2020), 125. 
ły (i nadal mogą) powstawać i funkcjonować różnorodne, wykluczające się idee religijne czy też teorie naukowe.

Tę intelektualną, poznawczą i ontologiczną sytuację można zilustrować, odwołując się do dzieł filozoficznych i naukowych. Na przykład Aleksander Koyré w książce Od zamkniętego świata do nieskończonego wszechświata w drugim rozdziale przeciwstawia dwa niemal współczesne sobie dzieła: Zodiacus vitae (1536) Palingeniusza (Marcellus Palingenius Stellatus) oraz De revolutionibus orbium coelestium (1543) Mikołaja Kopernika. Jak zauważa, są one kwintesencją tego odmiennego stylu myślenia, a więc i stylu uprawiania oraz rozumienia nauki ${ }^{3}$.

To odmienne podejście do przyrody skutkujące różnymi, wykluczającymi się wizjami wynikało z tego, iż w całości lub w obrębie niektórych zjawisk, takich jak ruch, natura była dla filozofów i przyrodników źródłem paradoksów ${ }^{4}$. Na przykład dla Zenona z Elei ruch implikował niemożność jego logicznego i przyrodniczego wyjaśnienia, co kłóciło się w sposób oczywisty z empirią. Jednakże ówczesne obserwacje były zbyt powierzchowne i ogólne, by mogły skutkować ścisłą i spójną wiedzą na temat różnych parametrów tego zjawiska, generując nierozstrzygalne logiczne kontrowersje. Dlatego też Galileusz swoje badania w tym zakresie mógł uzasadnić, nadając im następujący kontekst: „O bardzo starym przedmiocie przynosimy naukę zupełnie nową. Nie ma nic dawniejszego w naturze od ruchu, a pisma o nim filozofów są nieliczne i niewystarczające. Znam liczne i godne uwagi jego objawy, dotąd niezaobserwowane i niedowiedzione" ${ }^{\prime \prime}$. Dotyczyło to kwestii związanych

2 Ale także i religijna, która przekładała się na sferę polityczną, społeczna, artystyczną. Pojawienie się różnego rodzaju schizm świadczyło o mentalnej i psychologicznej możliwości myślenia niezależnego od oficjalnej wykładni. Herezje są świadectwem niezależności myślenia.

3 Por. Aleksander Koyré, Od zamkniętego świata do nieskończonego wszechświata, przeł. Ola i Wojciech Kubińscy (Gdańsk: Biblioteka Filozofii i Historii Filozofii, 1998), 40.

${ }_{4}^{4}$ Należy jednak dodać, że dla przyrodników, szczególnie okresu nowożytnego, takich jak Robert Boyle czy Isaac Newton, natura nie mogła być sprzeczna, nie mogła generować sprzeczności. Było to założenie (czy też jakaś intuicja) tyleż metafizyczne, co zdroworozsądkowe. Sprzeczność implikowałaby chaos, a przecież doświadczenie i matematycznie opisywalne zjawiska temu właśnie przecza; por. na przykład Isaac Newton, Matematyczne zasady filozofii przyrody, przeł. Jarosław Wawrzycki (Kraków: Copernicus Center Press, 2011), 536.

${ }_{5}$ Galileo Galilei, Rozmowy i dowodzenia matematyczne w zakresie dwóch nowych umiejętności dotyczących mechaniki i ruchów miejscowych, przeł. F.K. (Warszawa: Wydaw. Kasy im. Mianowskiego Instytutu Popierania Nauki, 1930), 114. Więcej na temat Galileuszowej metody geometryzacji badań ruchu por. Zbigniew Pietrzak, „O osobliwościach Galileuszowej filozofii matematyzacji nauk przyrodniczych", Lectiones $\mathcal{E}$ Acroases Philosophicae V, 1 (2012). Por. także Krzysztof Rotter, „Fizyka Galileusza a Arystotelizm. Przyczynek do roli krytyki w rozwoju wiedzy", Nowa krytyka 2 (1992). 
z przyspieszeniem, trajektorią lotu pocisków i „innych rzeczy nie mniej godnych uwagi" ${ }^{\prime}$.

Interesujące jest to, iż analizując zjawisko ruchu, można było także "coś" powiedzieć o własnościach przestrzeni, czasu, materii oraz siły. Mówiąc inaczej, badania nad własnością ruchu w jakiś sposób mogą charakteryzować przestrzeń, czas, materię i siłę.

Powiązanie ruchu z tymi aspektami przyrody sprawia, że jego analiza wymusza wręcz odwoływanie się do takich „bytów”, jak przyczynowość, jakość, ilość czy też próżnia, a więc w pewnym sensie do bytów metafizycznych. Owe przyrodnicze i metafizyczne aspekty towarzyszące badaniom ruchu (a w konsekwencji przestrzeni i czasu, siły i materii) umożliwiają powoływanie się na różnorodne zasady - filozoficzne (metafizyczne), matematyczne i empiryczne ${ }^{7}$. Te zaś determinują także metodę badań, a tym samym zakres poznania przyrody i w konsekwencji jej ontologię. Tym samym powstała sytuacja, w której te odmienne zasady, konstruujące odmienne perspektywy badawcze, zdeterminowały wizje świata przyrody. Co więcej, przeplatały się one, a nawet wzajemnie warunkowały. Ich separacja, pozornie oczywista, okazuje się jednak trudna, o ile w ogóle wykonalna. Świadczy o tym fakt, że uczeni, odwołując się do odmiennych zasad, dochodzą do podobnie brzmiących wniosków, a z drugiej strony, odwołując się na przykład tylko do zasad matematycznych, formułują wykluczające się twierdzenia. Ich wiara w zasadność i trafność wyboru tych czy innych zasad (perspektyw) to natomiast problem tyleż epistemologiczny i metodologiczny, co psychologiczny i religijny.

${ }^{6}$ Galilei, Rozmowy, 114.

7 Wieloznaczne pojęcie „zasada" użyte w tytule oraz na stronach niniejszego artykułu, pełniąc znaczącą funkcję konceptualna, wymaga krótkiego wyjaśnienia dotyczącego sposobu jego rozumienia. Odwołuję się przy tym do podanej przez Jacka Wojtysiaka systematyki. „Zasady filozofii”, , zasady matematyczne” czy też „,zasady empiryczne" można rozumieć w powiązaniu z charakterem „naczelnych twierdzeń" danej dziedziny (filozofii, filozofii przyrody). Innymi słowy, owe „naczelne twierdzenia" - według uczonego - mają charakter filozoficzny lub matematyczny. (Pomijam przy tym to, na ile uczony uważa, iż charakter ten ma obiektywny status, a na ile jest on pewnym konstruktem). Co więcej, owe „zasady" można traktować też jako metodologiczne postulaty dotyczące reguł postępowania badawczego. A zatem uczony działa zgodnie z metodami wypracowanymi przez filozofię, matematykę i nauki empiryczne. Owa wieloznaczność wskazuje na konieczność „wielowątkowej” interpretacji omawianych kwestii, a tym samym poszerza zakres rozumienia przedstawionej problematyki. To spowodowało, że nie użyłem pojęcia „założenie”, choć byłoby ono bardziej jednoznaczne. Por. Jacek Wojtysiak, „Zasada”, Encyklopedia filozofii przyrody, red. Zenon E. Roskal (Lublin: Wydawnictwo KUL, 2016): 323-44. 
W niniejszym artykule, analizując wybrane aspekty naukowych dokonań czterech uczonych, chciałbym podjąć próbę takiej separacji. Przy czym, co warto zasygnalizować już teraz, próbę, której efekty nie są jednoznaczne, a czasami prowadzą do wykluczających się wniosków.

Podobnie jak Koyré odwołam się do różnych dzieł, których treść i status (poznawczy, filozoficzny, metodologiczny i ontologiczny) ilustrują skrajnie odmienne perspektywy. Są nimi: Zasady filozofii (Principia philosophicae) z 1644 roku $^{8}$ René Descartes'a i wydane w 1687 roku Matematyczne zasady filozofii przyrody (Philosophiae naturalis principia mathematica) autorstwa Izaaka Newtona, a także Powszechna historia nieba Immanuela Kanta z 1755 roku $^{9}$ i Historia astronomii Pierre'a Simona de Laplace'a z 1796 roku $^{10}$.

\section{Filozoficzne i matematyczne zasady przyrody - ruch, sita i materia}

Konfrontując dwa dzieła: Zasady filozofii (1644) Descartes'a i Matematyczne zasady filozofii przyrody (1687), nie trzeba formułować tak radykalnej

${ }^{8}$ Wydanie w języku francuskim w 1647 roku. René Descartes, Zasady filozofii, przeł. Izydora Dąmbska (Kęty: ANTYK, 2001).

9 Pełny tytuł brzmi: Powszechna historia naturalna i teoria nieba albo szkic o układzie oraz mechanicznym pochodzeniu całości świata opracowany zgodnie z prawami Newtona; tytuł oryginalny: Allgemeine Naturgeschichte und Theorie des Hommels, oder Versuch von der Verfassung und dem mechanischen Ursprunge des ganzen Weltgebaudes nach Newtonischen Grunsätzen abgebandelt, 1755. Oba tytuły podaję za: Immanuel Kant. Dzieła zebrane, t. 1, „Pisma przedkrytyczne”, przeł. różni, red. Tomasz Kupś (Toruń: Wydawnictwo Naukowe Uniwersytetu Mikołaja Kopernika, 2010), 908 (tytuł oryginalny) i 195 (polskie tłumaczenie). Całość dzieła: 195-322. Szczególne znaczenie dla niniejszych rozważań ma: „Część druga. Rozdział pierwszy: O pochodzeniu systemu planet w ogólności oraz o przyczynach ich ruchów", 237-244. Por. także Andrzej Kajetan Wróblewski, Historia fizyki (Warszawa: PWN, 2009), 220. Warto także wspomnieć o Metaphisische Anfangsgrunde der Naturwissenschaft (1786), pol. Metafizyczne podstawy przyrodoznawstwa.

10 Pełny tytuł przekładu brzmi Historyia astronomii krótko zebrana przez markiza de Laplace, przeł. Wincenty Karczewski (Wilno: 1825). Tłumaczenie Karczewskiego zostało dokonane na podstawie oryginalnego dzieła Laplace'a z 1821 roku pt. Precis de l'histoire da l'astronomie (ok. 160 s.). Ten esej Laplace'a stanowi księgę V dzieła Expositiondu Systeme du Monde, które zaczęło się ukazywać w 1796 roku.

Na stronie internetowej Biblioteki UWr znajduje się PDF całego dzieła Laplace'a Expositiondu Systeme du Monde Expositiondu Systeme du Monde wydanego w jednym tomie - jest to V edycja z 1824 roku. Dla prezentowanej pracy najbardziej istotne idee Laplace'a zostały zawarte w rozdziale VI księgi V tego dzieła. W wymienionym wydaniu z 1824 roku rozdział ten obejmuje strony 388-400. 
opinii, którą przedstawił Koyré, by wskazać na ich fundamentalną odmienność, pomimo występujących w obu dziełach podobieństw. Analogii możemy doszukiwać się $\mathrm{w}$ ich konstrukcji, ponieważ opierają się na najbardziej ogólnych, fundamentalnych zasadach. Jednakże te zasady są względem siebie nieredukowalne. U Descartes'a są to zasady filozoficzne, u Newtona matematyczne. Determinują one treści samych dzieł, a tym samym także treści budowanych wzorców nowożytnej fizyki. W konsekwencji te dwa dzieła w wymiarze epistemologicznym, metodologicznym i ontologicznym reprezentują odrębne epoki, tak jak wspomniane wcześniej dzieła Palingeniusza i Kopernika.

Efekty badań Descartes'a i Newtona są ujęte w trzech „prawach":

Rene Descartes* - „prawa natury”:

Izaak Newton**: aksjomaty, czyli „prawa ruchu" (lub zasady dynamiki Newtona jak obecnie są one nazywane):

I. „Pierwsze prawo natury: że każda „I prawo: Każde ciało pozostaje w swym rzecz, o ile jest sama w sobie, zawsze stanie spoczynku lub ruchu jednostajnepozostaje w tym samym stanie, a także go po linii prostej, dopóki siły przyłożoto, co raz zostało w ruch wprawione, ne nie zmuszą go do zmiany tego stanu". zawsze dąży do ruchu".

II. „Drugie prawo natury: że każdy ruch „II prawo: Zmiana ruchu jest proporcjosam $\mathrm{w}$ sobie jest ruchem po prostej nalna do przyłożonej siły poruszającej i dlatego te ciała, które poruszają się i następuje wzdłuż prostej, wzdłuż której ruchem obrotowym, zawsze dążą do siła ta jest przyłożona".

oddalania się od środka koła, które

opisują".

III. „Trzecie prawo: jedno ciało, zderzając „III prawo: Każdemu działaniu towasię z drugim, silniejszym, nie traci nic rzyszy zawsze przeciwne i równe przeze swego ruchu; zderzając się jednak ciwdziałanie, to jest wzajemne działania ze słabszym, tyle traci, ile na tamto dwóch ciał na siebie są zawsze równe przenosi". i skierowane przeciwnie".

* Podaję za: Descartes, Zasady filozofii.

** Podaję za: Newton, Matematyczne zasady, 197.

Biorąc pod uwagę odmienne inspiracje leżące u źródeł cytowanych reguł/praw, zadziwia ich zbieżność. Nawet jeśli uwzględnimy, że mówią o tym samym: ruchu i sile. 


\section{Filozoficzne "zasady rzeczy materialnych" ${\text { Descartes' }{ }^{*}}^{*}$}

Punkt wyjścia dla Descartes'a to prawda zawarta w sądzie „myślę, więc jestem”. Ze względu na jej „pewność i oczywistość" jest ona niezachwiana i dlatego też może stanowić pierwszą zasadę filozofii ${ }^{11}$. I jako najbardziej fundamentalna poznawczo może również być podstawą dla innych dziedzin wiedzy, na przykład dla fizyki ${ }^{12}$. Można byłoby zatem rzec, że skoro taka właśnie filozoficzno-metafizyczna zasada (prawda) stanowi fundament dla Kartezjańskiej fizyki, to i jego koncepcja nauk przyrodniczych musi być „obciążona” ową metafizycznością ${ }^{13}$. Dlatego też Descartes pisze "zasady filozofii”, a nie „zasady matematyczne" czy też „empiryczne zasady filozofii przyrody" bądź "empiryczne zasady filozofii fizyki". Ten psychologiczny charakter owej zasady rzutuje na jego koncepcję i treść fizyki, nauk biologicznych oraz filozofii przyrody ${ }^{14}$.

Nim Descartes sformułuje własną „wersję" trzech praw natury, w części drugiej Zasad filozofii przeprowadzi szczegółową analizę dotyczącą istnienia materii, próżni oraz ruchu, zakładając, że wiedza o własnościach materii musi dotyczyć cech, które jawią się jako ,jasne i wyraźne", a więc takich, które mogą być przedmiotem geometrii1 ${ }^{15}$. Descartes dochodzi do wniosku, iż jedną z nich jest rozciągłość. Tak „zdefiniowanej” materii przysługuje podzielność, kształt jej części oraz zdolność do ich poruszania się ${ }^{16}$. Wyjaśniając zaś przyczyny ruchu, filozof wskazuje na Boga ${ }^{17}$. Ten pogląd "sam w sobie" nie determinowałby jeszcze owego metafizycznego tła w rozważaniach Descartes'a, ale gdy staje się zasadniczą perspektywą w jego dociekaniach, to przenika całość treści. Cena, jaką Descartes płaci za ów niewzruszony

" Por. „Część II - O zasadach rzeczy materialnych”; Descartes, Zasady filozofii.

11 Tenże, Rozprawa, 37.

12 Tamże, por. przyp. na stronach 38-39.

13 Por. tamże, 26.

14 Także i historii naturalnej.

15 Por. Descartes, Medytacje o pierwszej filozofii, przeł. Maria i Kazimierz Ajdukiewiczowie, Zarzuty uczonych mężów wraz z odpowiedziami autora, t. 1, przeł. Stefan Swieżawski (Warszawa: PWN, 2010), 70, 76 i in.

16 Descartes, Rozprawa, 43-44 oraz przyp. 128; por. także Descartes, Medytacje, 68. Własności te były uznawane za pierwotne czy też podstawowe przez większość filozofów i przyrodników, niezależnie od tego, czy byli empirykami, czy też skłaniali się ku matematycznemu ujęciu natury, o ile stali na stanowisku mechanicyzmu. Na przykład Robert Boyle zawsze wymieniał materię i ruch jako „zasady mechaniki", dodając niekiedy kształt, liczbę, położenie.

17 Poszukując przyczyn ruchu, widzi je dwojako: jako pierwotną i powszechną oraz jako szczegółową. 
fundament, jest całkowite uzależnienie swojej fizyki od Boga w sferze epistemologicznej i ontologicznej. Bóg warunkuje poznanie świata, a także jego istnienie ${ }^{18}$. Kartezjański świat przyrody funkcjonuje i jest dostępny naszemu poznaniu o tyle, o ile uwzględni się istnienie Boga.

Własności Boga, na które powołuje się Descartes, to Jego "doskonałość" implikująca "niezmienność" i sposób „działania” - również ",stały" i „niezmienny”. Skoro źródła ruchu Descartes wiąże z Bogiem i Jego własnościami, to aby być konsekwentnym, także i owe „prawa natury" dotyczące ruchu musi powiązać ze Stwórcą. Narzucając sobie taką perspektywę, traktuje Boga jako konieczny element swojej epistemologii i ontologii. Tak więc, uzasadniając sformułowane przez siebie trzy "prawa natury”, odwołuje się do własności Boga ${ }^{19}$.

Następnie Descartes, ponownie odwołując się do własności Boga, formułuje coś na wzór "zasady zachowania ruchu” („zasady ciągłości ruchu" ${ }^{20}$. Prowadzi to w ostateczności do konkluzji pozwalającej na zrozumienie obserwowanych w przyrodzie mechanizmów: "Skoro bowiem wszystko wypełniają ciała, a niemniej jednak ruch każdego ciała zmierza po linii prostej, widać stąd, że Bóg [...] sprawił, że jedne $\mathrm{z}$ nich dają impuls drugim, przenosząc na nie swoje ruchy. [...] W ten sposób nawet i ta ciągła zmiana rzeczy stworzonych dowodzi niezmienności Boga"21. Przyjęta ciągłość materii i ciągłość ruchu decyduje o tym, że świat jest plenum i że nie istnieje próżnia. Inaczej natura byłaby "porowata”, pełna luk i nieciągłości, a takie zjawiska jak ruch (w tym i nasze działanie) stałyby się czasowo i przestrzennie nieprzewidywalne i „nielokalizowalne". Przyroda byłaby niepoznawalna i niemożliwe byłoby sformułowanie innych zasad ${ }^{22}$. Co więcej, przytoczone powyżej „prawa natury będące drugorzędnymi lub szczegółowymi przyczynami różnych ruchów" ${ }^{\prime 23}$, ze względu na swój fundamentalny charakter, mogą stanowić podstawę do formułowania bardziej szczegółowych praw/reguł. Ale - podkreślmy to raz jeszcze owe "prawa natury" wynikają z założeń metafizycznych.

Poglądy Descartes'a, szczególnie w kontekście matematycznej koncepcji Newtona, jawią się jako skrajnie odmienne nawet w kwestii „ilościowego" ujmowania świata. Jak bowiem stwierdza Descartes, „chociaż ten ruch nie jest w poruszającej się materii niczym innym, jak tylko jej modyfikacją, to jednak przysługuje mu pewna określona

18 Descartes, Rozprawa, 45.

19 Tenże, Zasady, 70.

${ }^{20}$ Por. zasada zachowania energii sformułowana przez Gottfrieda Wilhelma Leibniza.

${ }^{21}$ Descartes, Zasady, 73.

${ }^{22}$ Tamże, 73 i n. Por. także tenże, Medytacje, 89-91, gdzie Descartes opisuje „ruch/ /przepływ bodźców".

${ }^{23}$ Tamże, 70. 
ilość [podkreśl. Z. P.], która - jak łatwo pojmujemy - może być zawsze taka sama w całej powszechności rzeczy, jakkolwiek zmienia się w poszczególnych jej częściach"24. Owa "suma” ruchów i spoczynku jest znowu uwarunkowana własnościami Boga, znowu więc Stwórca generuje tę immanentną własność świata ${ }^{25}$. Czy takie ujęcie ruchu, w którym „ilość" wydaje się naturalną (ontologiczną?) jego własnością pozwala na ilościowo-liczbowy opis? Czy w konsekwencji można wyprowadzić jakieś „,Kartezjańskie równania ruchu”?

$\mathrm{Z}$ analogiczną sytuacją mamy do czynienia, gdy rozważymy problem dotyczący geometryzacji ruchu, gdy spytamy o to, czy można opisać to zjawisko „narzędziami” geometrii Euklidesa? Czy może ono być przedmiotem rozważań geometrów, a tym samym, czy wnioski płynące z badań nad ruchem mogą być „pewne i wyraźne”? Dotyczą one także struktury i funkcjonowania Kosmosure ${ }^{26}$. Etienne Gilson w książce Jedność doświadczenia filozoficznego ${ }^{27}$, analizując problem Kartezjańskiej koncepcji matematyzacji przyrody, zauważa, że geometryczne wyjaśnianie wszelkich zjawisk przyrodniczych ( $w$ tym nawet życia) ma swoje ograniczenia. Geometria dotyczy rozciągłości, ale przyroda to także ruch, który - w tym kontekście - nie należy do porządku geometrycznego. Jest czymś zewnętrznym względem niego. Ruchu nie można wywieść z rozciągłości ciała, choć ono się porusza. Rozciągłość nie implikuje ruchu. Tak więc - jak sądzę - Kartezjańskie metafizyczne podstawy matematyzacji nauk przyrodniczych generują też zasadniczy problem dla matematycznego opisu ruchu. Nie jest on immanentnie wpisany $\mathrm{w}$ geometryczną rozciągłość substancji i tym samym $\mathrm{w}$ ontologię tak rozumianej przyrody. Jest czymś zewnętrznym. Ruch więc, jak wynika z fizyki Descartes'a, nie jest geometryzowalny. Zdaniem Gilsona usytuowanie zjawiska ruchu poza rozciągłością (a tym samym poza substancją cielesną) powoduje, że także jego źródła (przyczyny) muszą tkwić poza nią. Pozostaje więc odwołanie się do Boga ${ }^{28}$. Tym samym Descartes, aby stworzyć system dedukcyjny obejmujący całość zjawisk przyrodniczych, musi „uwikłać” je w metafizyczno-teologiczny kontekst ${ }^{29}$.

Dedukcyjność fizyki (ale także i biologii) polega więc na tym, że wszystkie zasady zostają wyprowadzone z tej jednej, fundamentalnej:

24 Tamże, 69.

25 Tamże.

26 Descartes, Rozprawa, 43, 46-47.

27 Etienne Gilson, Jedność doświadczenia filozoficznego, przeł. Zofia Wrzeszcz (Warszawa: Altaya de Agostini, 2001), 142-148.

${ }_{28}$ Tamże, 148. Jednakże musimy sobie uzmysłowić, że w tym czasie owej geometryzacji ruchu dokonuje Galileusz. Jego dzieło Rozmowy i dowodzenia jest pracą z geometrii, o strukturze przypominającej Elementy Euklidesa.

29 Descartes, Rozprawa, 49. 
"cogito ergo sum". Idea Kartezjańskiej fizyki, genialna konceptualnie, ale prowadząca do błędnych wniosków, ową "pewność i wyraźność" uzyskaną metodą dedukcyjną wiąże ze strukturami układów będących w ruchu bądź pozwalających na ruch. Dotyczy to zarówno struktur materii nieożywionej, jak i struktur biologicznych. W Rozprawie o metodzie filozof konstruuje ów geometryczno-dedukcyjny sposób pozwalający na połączenie obserwowanych struktur Kosmosu z ruchem jego elementów oraz na uzyskanie „jasności i wyraźności” poznania. Każdy potencjalny świat, Kosmos, przyroda ożywiona nie mogą inaczej wyglądać oraz funkcjonować niż świat, którego doświadczamy i w którym żyjemy. Powiązanie owych struktur Kosmosu z jego ruchem okazuje się bliskie Kantowskiemu postrzeganiu „systemu świata", kosmicznego porządku i grawitacji.

Reasumując, geometryzacja to pewien typ rozumowania, który wiąże się ze sposobem wnioskowania opartym na połączeniu przyjętych założeń (metafizycznych/filozoficznych) i empirycznych danych ${ }^{30}$.

Czy jednak i ewentualnie jak ową racjonalność i dedukcyjność można powiązać z metafizyką? Czy metafizyka może być racjonalna, czy racjonalna geometria może być metafizycznie uwarunkowana (a tym samym i cała racjonalność)? Otóż Descartes twierdzi, że zasada metafizyczna jest zgodna $z$ rozumem ${ }^{31}$. Twierdzenia: Bóg zachowuje zawsze tę samą ilość ruchu; stworzył materię i w całości zachowuje ją taką samą; przyroda nie znosi próżni - nie gwałcą ludzkiej racjonalności, ludzkiego intelektu.

\section{Zasady matematyczne Newtona}

Newton już w przedmowie do Principiów... deklarował, że badane zjawiska przyrody będzie opisywał zgodnie z prawami matematyki. Interesujący jest pewien szczegół w jego wypowiedzi: „i ja będę uprawiał matematykę w takim stopniu, w jakim dotyczy ona filozofii" 32 . Dalej uszczegóławia swoją myśl: „zajmujemy się tu bardziej filozofią przyrody niż sztukami mechanicznymi [zajmującymi się ruchem ciał] i piszemy raczej o siłach przyrody, [...] więc koncentrujemy się głównie na tych rzeczach, które dotyczą grawitacji [ciążenia], lekkości, sił elastycznych, oporu cieczy"33; i dodaje, że "całe zadanie filozofii przyrody polega na wyznaczaniu sił z zaobserwowanych ruchów,

\footnotetext{
30 Tamże, 59, por. przyp. 176.

31 Descartes, Zasady, 70.

32 Newton, Matematyczne zasady, 175.

33 Tamże, 176.
} 
a następnie - mając już te siły - na przewidzeniu dalszych zjawisk" ${ }^{\prime \prime}$. W tym określeniu filozofii jako filozofii przyrody i ujęciu jej w matematycznych zasadach wyraża się cel dzieła, sposób poznania przyrody oraz $w$ pewnym sensie styl uprawiania filozofii przyrody. Chciałoby się rzec, że również i styl uprawiania filozofii w ogóle.

Jak Newton realizuje to zamierzenie? Formułowane na podstawie obserwacji twierdzenia są udowadniane (konstruowane) matematycznie $^{35}$, powiązane $\mathrm{z}$ matematycznymi zasadami. Następnie stają się podstawą umożliwiającą „wyznaczenie” siły grawitacji. To z kolei pozwala na dedukcję „ruchów planet, komet, Księżyca oraz mórz na podstawie innych - również matematycznych - twierdzeń" ${ }^{\prime 36}$. Można zatem, dedukując z opisanych matematycznie sił natury, "zbudować" strukturę Układu Słonecznego. Powiązanie wszystkich „zjawisk natury" z siłami zdefiniowanymi (skonstruowanymi) matematycznie lub z siłami wydedukowanymi z tych pierwszych pozwala w konsekwencji na matematyczny opis świata ${ }^{37}$. Podkreślmy, z siłami, które łączą lub odpychają ciała, kształtując w ten sposób otaczającą materię, co umożliwiało matematyzację wiedzy o naturze. W ten sposób zdefiniowana natura nabiera matematycznych własności, a ontologia przyrody staje się ontologią matematyki i zostaje nią zastąpiona. Czy tę ontologiczną "transformację" wyraża filozofia absolutnego czasu, przestrzeni i ruchu, filozofia, która przeciwstawia ten sposób własnościom względnym, pozornym i powszechnym?

Newton, badając ruch i szukając dla niego matematycznych podstaw, jak pisze Michał Tempczyk, nie interesował się problemem pustej przestrzeni i absolutnego czasu, które byłyby pozbawione

34 Tamże.

35 Mówiąc o matematycznym udowadnianiu praw przyrody, a więc i jej matematyzacji, należy pamiętać, że do początku XVIII wieku mówimy o geometryzacji przyrody. Newton, podobnie jak Kopernik i Galileusz, do swoich badań wykorzystywał geometrię, jednakże dostrzegał jej ograniczenia. Jak pisze Edwin A. Burtt, Newton widział uniwersalny charakter arytmetyki i algebry. To te dyscypliny, a nie geometrię, uznawał za najbardziej przydatne narzędzia badania przyrody. Być może - według Burtta - był to powód tego, że Newton zaczął rozwijać analizę matematyczna, a nie nową geometrię (s. 210). Jednakże - zdaniem tego autora - Newton mało interesował się czystą matematyka, która nie rozwiązywałaby problemów fizycznych (s. 214). W przeciwieństwie do Newtona Laplace preferował czystą matematykę. Jej zastosowanie miało być tylko sprawdzianem jej przydatności do badań przyrodniczych. Por. Edwin A. Burtt, The Metaphysical Foundations of Modern Physical Science (New York: Doubleday, 1926).

36 Newton, Matematyczne zasady, 176.

37 Voltaire posuwa się nawet do stwierdzenia, że owe matematyczne dociekania mogą być źródłem wiedzy o „prawdziwych atomach”, które Newton uznawał, podobnie jak Pierre Gassendi; por. Wolter, Elementy filozofii Newtona, przeł. Helena Konczewska (Warszawa: PWN, 2010), 52. 
jakichkolwiek przedmiotów, bo to - zgodnie ze stanowiskiem Newtona - można było sobie jakoś wyobrazićs ${ }^{3}$. Z kolei według Descartes'a nie było to możliwe; uważał on, że pustej przestrzeni nie ma, ponieważ nie istnieje próżnia, a poza tym, czym miałby być absolutny czas, niezależny od Boga i poza Bogiem? Różne rozumienie absolutności (względności) niektórych aspektów przyrody było konsekwencją uznania takiej, a nie innej roli metafizyki w badaniach natury. Wedle Newtona absolutny czas i przestrzeń są czasem i przestrzenią matematyczna, prawdziwą ${ }^{39}$. Dotyczy to także wielkości: „względne wielkości nie są rzeczywistymi wielkościami [...], ale ich mierzalnymi miarami" 40 , czyli dającymi się pomierzyć relacjami między elementami ciała i (w pewnym sensie) przestrzeni. Zatem absolutny czas, przestrzeń i wielkości są prawdziwe i rzeczywiste, ale nie są mierzalne. Matematyka odnosi się „do samych wielkości mierzonych, a nie do ich miar"41 i jest podstawą miar oraz warunkuje pomiar. W konsekwencji zamiar wykorzystania matematyki wymaga jakiegoś zredukowania badanego przedmiotu (bytu) do tych jego własności, które mogą być mierzalne. $Z$ absolutnej przestrzeni, czasu i ruchu należy także wygenerować „elementy" spełniające ten warunek. Zadaniem zaś przyrodnika jest ich odszukanie. To sprawia, że tak naprawdę tworzy on pewien konstrukt. W tym też tkwi geniusz uczonego, który potrafi wskazać elementy oddające "istotę" badanego zjawiska, ale istotę matematyczną (lub empiryczną), a nie metafizyczną. Także uczony decyduje o tym, co stanowi ową istotę przedmiotu ${ }^{42}$. Oznacza to, że empiria nie kłóci się z matematycznym, abstrakcyjnym opisem. Innymi słowy, przyrodnik dokonuje pewnego wypreparowania natury z jej absolutnych (właśnie metafizycznych, filozoficznych) cech. „Bycie mierzalnym” oznacza "bycie względnym”, „nie-rzeczywistym”.

Związki matematyki i filozofii (filozofii przyrody) w pracy Newtona stanowią niejako oś jego rozważań ${ }^{43}$ oraz mają charakter metodologiczny. I w tym kontekście można doszukiwać się wzorców w filozofii Descartes'a. Owe związki z „zasadami filozofii" możemy dostrzec w „Księdze III. O układzie świata” w części „Reguły rozumowania w filozofii" ${ }^{44}$. Jak Newton rozumie owe „zasady"? Otóż pisze tak: „W POPRZEDNICH KSIĘGACH [pisownia jak w tłumaczeniu]

38 Michał Tempczyk, Ontologia świata przyrody (Kraków: Universitas, 2005), 15.

${ }^{39}$ Newton, Matematyczne zasady, 190.

40 Tamże, 195.

41 Tamże.

${ }^{42}$ Historia i filozofia nauki uzmysławiają że zdanie w tej kwestii ma również „społeczność uczonych", a i czasami „fakty”.

43 Por. „Przedmowa autora”, w: Newton, Matematyczne zasady, 176.

44 Tenże, Matematyczne zasady, 535-536. 
sformułowałem zasady filozofii ${ }^{45}$, zasady nie filozoficzne [czyli: nie metafizyczne jak u Descartes'a], lecz matematyczne, tzn. takie, na których można oprzeć rozumowania [podkreśl. Z. P.] w filozofii. Zasady te są prawami i warunkami ruchu sił, które są szczególnie związane z filozofią" ${ }^{\prime 46}$. Matematyczne zasady są więc także regułami myślenia, które porządkują je logicznie i eksplanacyjnie (czyli tak, jak postulował Descartes) ${ }^{47}$. Matematyka narzuca więc pewne rygory myślenia, wyznacza mu granice dowolności w spekulacjach, umożliwia (warunkuje) również poprawną heurystykę. W konsekwencji matematyka (czyli mechanika) wymusza odrzucenie bytów determinujących wizję przyrody od czasów Arystotelesa, "form substancjalnych" i „ukrytych jakości" ${ }^{48}$. Zgodnie z trzecią regułą myślenie matematyczne pozwala na działanie wykraczające poza rzeczywiste działanie sił natury: możemy bowiem materię podzielić na mniejsze części (cząstki), które są już niepodzielne w sposób naturalny ${ }^{49}$. Jednakże można zadać sobie pytanie, czym różni się takie „myślenie matematyczne” od „zwykłych" (filozoficznych?) spekulacji ${ }^{50}$. Jeżeli owe filozoficzne komentarze będą rozumiane jako komentarze w ramach filozofii przyrody, to jej związki z matematycznymi zasadami uchronią owe komentarze od jałowych spekulacji, niekonkluzywności i poza-empirycznej kontroli.

Charakteryzując stanowisko Newtona w poruszanej kwestii, można podsumować je następująco ${ }^{51}$. Jego przyrodoznawstwo (filozofia przyrody) jest ufundowane na matematyce, mechanice, a nie na filozofii; opisując matematycznie zjawiska ruchu i sił (mocy) przyrody, można wyprowadzać filozoficzne wnioski, które są zasadami czy też

45 Nawet jeśli zawęzimy - jak sugeruje to tłumacz dzieła - rozumienie użytego przez Newtona terminu filozofia do filozofii przyrody jako nauki „zajmującej się badaniem sił natury", to i tak filozofia pełni inną funkcję niż w systemie Descartes'a. Oferuje/dostarcza inne podstawy niż matematyka, a tym samym wymusza odmienną perspektywę, inne metody badawcze oraz odmienną narrację $\mathrm{w}$ opisie przyrody. To, co łączy Descartes'a i Newtona w tym kontekście, to wiara, że stosowane przez nich metody pozwalają na „posiłkowanie się rozumem”; Descartes, Rozprawa..., 25.

${ }^{46}$ Newton, Matematyczne zasady, 535.

47 Skojarzenia, jakie nasuwają się z „regułami myślenia” sformułowanymi przez Descartes'a w Prawidłach.... oraz w Rozprawie o metodzie, są metodologicznie uzasadnione, choć ich treść nieco się różni. Pełnią bowiem tę samą funkcję - porządkują myślenie, wnioskowanie. Nadają metodyczny, systematyczny charakter czynnościom intelektualnym, a także i praktycznym. Porządek intelektualny przekłada się na porządek w działaniu. Owe reguły mają umożliwić skuteczność i "prawdziwość" obu poznawczych zdolności człowieka.

${ }^{48}$ Wróblewski, Historia, 128-131.

49 Newton, Matematyczne zasady, 537.

50 Por. tamże, przyp. 471, 538.

${ }^{51}$ Wróblewski, Historia, 128-131. 
prawami i warunkami pewnych ruchów oraz sił (mocy). Następnie na ich podstawie można formułować filozoficzne wyjaśnienia dotyczące rzeczy o ogólnej (uniwersalnej) naturze, takich jak gęstość, opór, próżnia, ruch światła i dźwięku. Jednak owa uniwersalność nie wynika z metafizycznych idei Boga, ale z własności natury wygenerowanych dzięki matematycznemu ujęciu. Tak więc jeżeli nawet u podstaw „matematycznego kosmosu" Newtona pierwotnym jest Kosmos o absolutnych własnościach (czas i przestrzeń), co czyni go równie metafizycznym jak w koncepcji Descartes'a, to wprowadzenie matematyki do badań Kosmosu czyni zeń obiekt mierzalny. Dzięki temu ostatecznie może zaproponować matematycznie uzasadnioną strukturę świata (dziś powiedzielibyśmy: model) i odpowiedzieć na pytanie, jak „urządzony" jest świat.

$$
* * *
$$

W 1750 roku Thomas Wright napisał, że wszystkie obserwowane gwiazdy tworzą spłaszczony dysk, który obraca się wokół osii ${ }^{52}$ Zarówno Kant, jak i Laplace zgadzali się w tej kwestii. Inne obserwacje również prowadziły do wspólnych wniosków: wszystkie planety krążą w jednej płaszczyźnie (z pomijalnymi odchyleniami), podobnie jak satelity poszczególnych planet ${ }^{53}$. Kant dodawał też, że mgławice to także układy gwiazd, takie jak Droga Mleczna ${ }^{54}$. Laplace zaś dodawał, że stan (struktura) Układu Słonecznego przypomina efekt kondensacji materii w kilku „punktach" 55 . Kanta i Laplace'a łączyły empiryczne przesłanki, ale dzieliły odmienne zasady: Kant przyjął metafizyczno-matematyczną perspektywę, Laplace stricte matematyczną. W efekcie obaj uczeni stworzyli systemy bardzo podobne, choć jest to pozorne podobieństwo.

52 Według: tamże, 554. Możliwość fundamentalnych jakościowo i ilościowo zmian stanów przyrody i formowania się obiektów kosmicznych i Kosmosu dopuszczał już Descartes; por. Descartes, Rozprawa, 54. Dość powszechnie są znane z historii i filozofii nauki poglądy w tej kwestii formułowane przez Georges'a Buffona; por. Wróblewski, Historia, 220. Por. też I. Kant, Allgemeine Naturgeschichte (1755) w polskim przekł.: Powszechna historia naturalna i teoria nieba albo szkic o układzie oraz mechanicznym pochodzeniu całości świata opracowany zgodnie z prawami Newtona; przyp. 19, s. 912.

53 Kant, Powszechna historia naturalna, 215.

54 Wróblewski, Historia, 554.

55 Tamże, 220. 


\begin{tabular}{|l|l|}
\hline \multicolumn{1}{|c|}{ Twierdzenia Kanta* } & \multicolumn{1}{c|}{ Twierdzenia Laplace'a } \\
\hline Planety tworzą się z dala od Słońca. & $\begin{array}{l}\text { Planety tworzą się z materii atmosfery } \\
\text { Słońca. }\end{array}$ \\
\hline $\begin{array}{l}\text { Jednym z czynników planetotwórczych } \\
\text { jest różnorodność materii, a nie wysoka } \\
\text { temperatura. }\end{array}$ & $\begin{array}{l}\text { Jednym z czynników planetotwórczych jest } \\
\text { wysoka temperatura, a nie jest } \\
\text { nim różnorodność materii. }\end{array}$ \\
\hline Planety powstają jednocześnie. & $\begin{array}{l}\text { Planety powstają kolejno po sobie w du- } \\
\text { żych odstępach czasu. }\end{array}$ \\
\hline $\begin{array}{l}\text { Planeta najdalej od Słońca odległa jest } \\
\text { najmłodszą. }\end{array}$ & $\begin{array}{l}\text { Planeta najdalej od Słońca odległa jest } \\
\text { najstarszą. }\end{array}$ \\
\hline $\begin{array}{l}\text { Komety mają wspólne ze Słońcem pocho- } \\
\text { dzenie. }\end{array}$ & $\begin{array}{l}\text { Komety nie mają ze Słońcem wspólnego } \\
\text { pochodzenia. }\end{array}$ \\
\hline
\end{tabular}

* Podaję za: Hersch Bad, Geneza i zmierzch legendy Kant-Laplace (Lwów: Wydawnictwo Księgarni M.H. Rubina 1931). Przedruk w: Hersz Bad, „Geneza i zmierzch legendy Kant-Laplace", Studia z Historii Filozofii 3, 2 (2015): 46-76. Podobieństwo w zasadniczych kwestiach kosmologii Kanta i Laplace'a spowodowało, że połączono je, nadając im nazwę „hipoteza Kanta-Laplace'a”. Zabieg ten sugeruje nie tylko teoretyczną (logiczną), ale także empiryczną i metodologiczną jedność czy spójność. Tymczasem jest ona pozorna, co wzmacnia pogląd zaprezentowany w niniejszej pracy o odrębności obu koncepcji, pomimo ich zasadniczych podobieństw. Por. Bad, „Geneza i zmierzch legendy Kant-Laplace”, 52 oraz Anna Szyrwińska, „Z badań nad filozofią Kanta w kręgu Szkoły Lwowsko-Warszawskiej: Hersz Bad o teorii Kanta-Laplace'a", Studia z Historii Filozofii 3, 5 (2014). Prace te tylko $\mathrm{w}$ niewielkim stopniu bezpośrednio dotyczą poruszanych $\mathrm{w}$ niniejszym artykule kwestii w kontekście Kanta i Laplace’a.

\section{Metafizyczno-matematyczna perspektywa i argumentacja Immanuela Kanta}

Pomimo że w tytule podrozdziału sygnalizuję metafizyczny aspekt Kantowskiej argumentacji, to chciałbym na początku zwrócić uwagę na fizykalne (empiryczne) założenia, które składały się na system przyrody tego filozofa, przeplatając się z metafizyczno-matematyczną perspektywą. Wynika to zresztą z treści tytułu omawianego dzieła, w którym Kant explicite odwołuje się do mechaniki Newtona. Wychodząc od obserwacji ruchów i struktury („,systemowości”) Układu Słonecznego, Kant dochodzi do wniosku, że geneza układu musi być efektem procesu, a nie jednorazowego naturalnego zdarzenia (lub aktu stworzenia). Także jego funkcjonowanie musi mieć procesualny charakter. Dane empiryczne i mechanika Newtona z jej matematycznymi (i metafizycznymi) zasadami i heurystyką pozwalają na to, by wiarygodnie - wedle Kanta - ów procesualizm uzasadnić i zrekonstruować. Kant uważał także, że rozważania i płynące z nich wnioski można odnieść również do historii for- 
mowania się, struktury i mechaniki Drogi Mlecznej, a ostatecznie i do Kosmosu. Jednakże analiza tej i innych prac poświęconych zjawiskom przyrodniczym oraz leżących u ich podstaw założeń pozwala na stwierdzenie, że zasady mechaniki Newtona Kant traktował jako wtórne (zależne) względem fundamentalnych założeń metafizycznych i że mógł sprowadzić je do tych ostatnich. Na czym więc polega ów metafizyczny i teologiczny komponent myśli Kanta w omawianym kontekście?

Zdaniem Kanta pierwotny stan materii charakteryzował się rozproszeniem, „bezforemnością”. Można postawić tezę, że filozof ten nawiązuje do opisywanego w Biblii „,chaosu"56, który był jakimś „prastanem” przyrody w jej kosmicznej skali, ale być może także przyrody na Ziemi. Według tej koncepcji przyroda posiadała zatem jakiś naturalny, „boski” stan, a więc w pewnym sensie pierwotny i wyróżniony. Taka wizja natury jest metafizycznym założeniem i jednocześnie wskazuje na coś, co można byłoby nazwać „istotą materii". Jednakże owa intuicja „pierwotnego chaosu" została wydedukowana z bezpośrednich obserwacji. Te zaś zmuszały do wniosku, że ów wyróżniony stan chaosu i bezładu został następnie przeorganizowany, to znaczy uporządkowany. A zatem był on tylko jakimś etapem w procesie kształtowania się Kosmosu, co oznaczałoby, że nie mógł być jego „istotą". Zdaniem Kanta (i Laplace'a) owo porządkowanie zachodziło dzięki działaniu sił przyrody: grawitacji i siły odśrodkowej. Tu oczywiście Kant odwołuje się do zasad mechaniki Newtona, które stają się narzędziem umożliwiającym mu uzasadnienie swoich idei. Siły te - według Kanta - są immanentnymi własnościami przyrody ${ }^{57}$. Jednakże $\mathrm{w}$ jakim sensie owa zdolność (,skłonność") materii do wychodzenia z chaosu tkwi w niej samej? Czy materia "sama w sobie” miałaby taką własność, taką „moc"? Gdyby przyjąć te założenie, mielibyśmy do czynienia z materializmem, a nawet panteizmem. By uniknąć takiej konkluzji, Kant musiał odwołać się do Boga - to Stwórca powinien stać za wszystkimi mechanizmami, wedle których funkcjonuje natura i które prowadzą ją ku porządkowi ${ }^{58}$.

Jednak obecność i aktywność Boga w filozofii przyrody Kanta w przeciwieństwie do koncepcji Descartes'a - jest bardzo subtelna i dyskretna. „Niedoskonałości” przyrody, jej „wady” dostrzegane w funkcjonowaniu Kosmosu świadczą o tym, że Bóg nie działa bezpośrednio, a tylko za pomocą wcześniej ustanowionych praw. Gdyby Bóg wpływał

56 Por. Descartes, Rozprawa, 54.

57 Kant, Powszechna historia, 239-240.

58 Podobny kontekst towarzyszy zarzutom formułowanym pod adresem teorii ewolucji. Jej krytycy, mniej lub bardziej wprost, twierdza, że odrzucenie Boga jako stwórcy przyrody (i może nawet jej ewolucji) implikuje to, że materia „sama w sobie", "sama z siebie" potrafiła wygenerować zmiany ilościowe i jakościowe prowadzące od protonu i elektronu do umysłu człowieka. Innymi słowy, że siła kreacji tkwi w samej materii. 
na przyrodę bezpośrednio, musiałaby ona być doskonała, idealna, tak jak geometria i jej przedmioty. Tymczasem dzięki obserwacji wiemy, że tak nie jest. Świat, choć geometrycznie opisywany, nie składa się z idealnych obiektów, idealnych linii i okręgów, kątów prostych itp. Kant, uznając prawa Newtona za powszechne oraz niezbędne do prawidłowej rekonstrukcji powstania Układu Słonecznego, krytykuje jednak jeden z podstawowych elementów filozofii przyrody tego uczonego: potrzebę odwoływania się do bezpośredniej ingerencji Boga w przyrodę, choćby tylko akcydentalnej. Uważał, iż takiemu stanowisku przeczą świadectwa empiryczne, matematyczne i logiczne ${ }^{59}$.

Tak jak już wspomniałem, według Kanta za dostrzeganym w przyrodzie porządkiem (choć nie idealnym) musi stać jednak jakiś intelekt ${ }^{60}$. Kant jednakże buduje inną niż Descartes i Newton relację między prawami przyrody a Bożą obecnością (aktywnością) w materialnym świecie. Wedle niego "natura i wieczne prawa" przypisane "substancjom” nie są samoistnym względem Boga "principium” " zgodność zaś i porządek między prawami a substancją świadczą o tym, że muszą one uczestniczyć w "praistocie”. „Dlatego też - pisze filozof - natura musi ukazywać nic innego, jak stałe wzajemne związki i harmonię, ponieważ ich właściwości mają swe źródło w jednym najwyższym rozumie" ${ }^{\prime \prime 2}$. Zatem ów rozum „wszczepia” im "możność" warunkującą zaistnienie (realizację) porządku i dzięki temu wydobywa "prawdziwe piękno" z tak „urządzonej” przyrody ${ }^{63}$. Jeśli bowiem - jak pisze Kant - twierdzi się, ,że powszechne prawa przyrody same w sobie prowadzą tylko do nieporządku", to obserwowana harmonia musi być efektem bezpośredniej interwencji Boga, a to oznacza, że natura istnieje dzięki cudom. Tak więc mamy alternatywę - albo uznamy, że przyroda funkcjonuje dzięki „zaszczepionej” (przez Boga) w prawach przyrody możności generowania porządku i harmonii, albo jej stan jest wynikiem cudu. Oryginalność teorii Kanta i jego sposobu wykorzystywania zasad metafizyki do opisu przyrody polegała na uznaniu tego pierwszego wniosku.

Powołanie się na bezpośrednie działanie Boga, a nie na prawa przyrody, sprawiałoby również, że nie można byłoby wyjaśnić na przykład położenia planet, ich ruchów, trajektorii itp. bez popadania w sprzecznośćc ${ }^{64}$. Nie ma bowiem powodów, poza naturalnymi przyczynami, aby „ciała niebieskie" poruszały się w jednym kierunku. Kant podkreśla, że taka jednorodność przeczy Boskiej twórczej mocy: „wola Boska nie

\footnotetext{
${ }^{59}$ Kant, Powszechna historia, 238.

60 Tamże, 294.

61 Tamże, 295.

62 Tamże.

63 Tamże.

64 Tamże, 298.
} 
miałaby najmniejszego powodu, by ograniczać się w jeden określony sposób, ale raczej powinna objawiać się z większą swobodą we wszelkiego rodzaju zmianach i różnorodności" ${ }^{65}$. Można byłoby więc zapytać, dlaczego Bóg miałby w ten sposób ograniczać swoją „kreatywność”. Kant zauważa, że gdyby Bóg bezpośrednio ingerował w działanie przyrody, to orbity planet powinny leżeć $\mathrm{w}$ jednej, idealnej płaszczyźnie, co odpowiadałoby boskiej doskonałości. Tymczasem istnieją, choć nieznaczne, odchylenia od niej. Są one jednak na tyle niewielkie, że możemy mówić o zadziwiającej jednorodności i harmonii struktury Układu Słonecznego. I jest to argument za tym, że nie może być ona przypadkowa, a owe „niedoskonałości" wskazują na efekty działań naturalnych mechanizmów, a nie na bezpośrednią Boską ingerencję. Natura i zjawiska przyrodnicze nie mogą być idealne - takie nie są bowiem ani materia, ani mechanizmy regulujące jej ruch. Jednakże muszą być wynikiem funkcjonowania sił porządkujących przyrodę, a nie ją destabilizujących ${ }^{66}$. Co więcej, odwołanie się do owych sił porządkujących jest argumentem na rzecz teorii ewolucyjnego powstawania naszego systemu planetarnego.

Kant podkreśla, że jego propozycja rozwiązuje trudności, z którymi nie potrafiła uporać się teoria Newtona ${ }^{67}$.

Bóg w kosmologii Kanta, mimo że nie jest bezpośrednio „zaangażowany" w funkcjonowanie przyrody, jest stale obecny i staje się punktem odniesienia dla empirycznej (przyrodniczej) i logicznej perspektywy. Nawet wówczas, gdy filozof ten bezpośrednio nie odwołuje się do Niego. Sądzę jednak, że Kant nie byłby w stanie uzasadnić swojej kosmologii bez Boga tak, jak zrobili to Descartes i Newton. I w tym upatruję ową metafizyczność teorii Kanta i jej fundamentalny charakter względem innych zasad: matematycznych, empirycznych czy też logicznych.

Metafizyczny i przyrodniczy (fizykalny) „program” Kanta opierał się na poszukiwaniu jedności w doświadczeniu fizycznym i metafizycznym. Dlatego też jego rozprawy przyrodnicze (a może raczej „przyrodnicze") były immanentnie warunkowane założeniami metafizycznymi,

65 Tamże.

${ }^{66} \mathrm{~W}$ tym kontekście pojawia się jednak pewna niekonsekwencja w argumentacji Kanta. Jeżeli bowiem jeden kierunek ruchu planet świadczy o jego naturalnym pochodzeniu, Bóg mógł przecież sprawić, by planety krążyły w różnych kierunkach, to dlaczego odchylenia płaszczyzn orbit planet miałby świadczyć o naturalnych przyczynach? Przecież różne nachylenie tych płaszczyzn realizuje owe oczekiwane wobec działań Boga zróżnicowanie. Ten argument w tym wypadku nie sprawdza się. Odchylenia te są minimalne, ledwo dostrzegalne. Nie zaburzają więc naturalnej harmonii i porządku przyrody, a zarazem sprawiaja, iż nie jest on idealny. Gdyby jednak miały mówić coś o Boskiej kreatywności, to owo zróżnicowanie świadczyłoby raczej o twórczym „minimalizmie” Boga. Dlaczego Stwórca miałby różnicować kąty płaszczyzn orbit w tak niewielkim stopniu?

67 Kant, Powszechna historia, 300. 
u podstaw których leżało pytanie o ostateczne przyczyny rzeczywistości $^{68}$. Kosmologia Kanta nie mogła się obejść bez Boga, lecz jego fizykalizm nie pozwalał na to, by wyjaśniając genezę i mechanizmy rządzące ruchem w Kosmosie, bezpośrednio odwoływać się do Stwórcy. Kant w ten sposób "skazywał" się na nieustanną ambiwalencję - chcąc być przyrodnikiem, powinien zrezygnować z dociekań metafizycznych; to kłóciło się z jego zasadniczym celem/zadaniem filozofii, czyli poszukiwaniem wspólnych związków między tymi obszarami. Przyroda bez Boga była dla Kanta tak samo niemożliwa jak dla Descartes'a. Ale każdy z nich, ze względu na swoją epistemologię, „lokował” Boga w innym miejscu w swojej teorii poznania.

A zatem gdy Laplace buduje swój system w oparciu o matematykę, to czy zamieniając owe Kantowskie zasady fizyczne na zasady matematyczne, nawiązuje ponownie do Descartes'a czy też do Newtona? To, co na pewno różni Laplace'a od jego poprzedników, to programowe odcięcie się od Boga i uwolnienie zasad od „hipotezy stwórcy” - o ile uznamy, że owo przekonanie Laplace'a jest metodologicznie wykonalne i szczere, a także nieuwarunkowane psychologicznie.

\section{Pierre Simon de Laplace - świat sił, czyli świat bez Boga}

XVIII wiek, szczególnie we Francji, charakteryzował się programowym wręcz rugowaniem „hipotezy Boga” z nauki i czymś w rodzaju intelektualnej mody na ateizm. Co prawda idea naturalizmu (i materializmu) w nowożytnej nauce sięga XVII wieku, ale dopiero sto lat później staje się konsekwentnie postulowanym i praktykowanym stanowiskiem metodologicznym i epistemologicznym w wiedzy przyrodniczej.

Aby realizacja tego programu była możliwa, świat przyrody musiały wypełnić oddziaływania, które przynależały do samej natury i które tłumaczyłyby wszystkie postrzegane zjawiska - od kosmicznych i ziemskich do kapilarnych oraz, być może, korpuskularnych. Laplace do pewnego stopnia określił ich własność, pisząc, że „można wyjaśnić zjawiska [...], przyjmując istnienie sił przyciągających i odpychających, które działają tylko na niedostrzegalnie małych odległościach [...]. Wszystkie zjawiska na ziemi zależą od sił tego rodzaju, podobnie jak zjawiska niebieskie zależą od powszechnej grawitacji" ${ }^{69}$. To umożliwiało odejście od abstrakcyjnych bytów (takich jak na przykład ciała sztywne) i przejście do realnej przyrody.

${ }_{68}$ Gilson, Jedność doświadczenia filozoficznego, 166.

${ }^{69}$ Wróblewski, Historia, 214. 
Odwoływanie się do sił funkcjonujących w przyrodzie i organizujących jej strukturę, które można było opisać matematycznie, świadczyło o tym, że mają one realny, niemetafizyczny (abstrakcyjny) charakter. Co więcej, takie rozumienie sił i skutków ich działania (na przykład "atrakcyje”, czyli przyciaganie) uzmysławiało, iż nie są to jakieś tajemne, ukryte elementy przyrody, jak Arystotelesowskie i Kartezjańskie byty („formy substancjalne” i „ukryte jakości”) ${ }^{70}$. Zatem matematyczne (ilościowe) ujęcie tych oddziaływań sprawiło, że przestały być one metafizyczne. Także możliwość ich matematycznego opisu świadczyła, iż nie są to byty metafizyczne. Poza tym dzięki matematyzacji można wyniki ekstrapolować, a działania tak rozumianych sił oraz oddziaływania między ciałami stają się przewidywalne. Rządzą bowiem nimi jakieś stałe, racjonalne (a nie metafizyczne, mistyczne) reguły. Analiza matematyczna jest także skuteczna jako „probierz", sprawdzian ich realności ${ }^{71}$. Dzięki temu, jak podkreśla Laplace w odniesieniu do teorii Newtona, istnieje zgodność między nią a zjawiskami, czego nie da się powiedzieć o teorii Descartes'a $^{72}$. Tak więc dla Laplace'a historia astronomii była źródłem przekonania o heurystycznej wartości metody matematycznej i samej matematyki jako ",języka natury”, fizykę traktował on zaś jako sprawdzian dla matematyki ${ }^{73}$.

Prostota skutków działania praw przyrody sprawia, że uczeni mogą domniemywać, iż owe mechanizmy, wedle których funkcjonuje natura, są również proste, a ich obserwowalne efekty mogą być ujęte $\mathrm{w}$ proste formuły. Świadczyłoby o tym przekonanie Laplace'a o prostocie (i efektywności) teorii Newtona. Zauważa on, że w jej ramach Newton „wznosi się do początku ciążenia powszechnego", a "geometrowie, stosując do niego analizę", wyprowadzają wszystkie inne zjawiska. Prostota praw opisujących fundamentalne, to znaczy podstawowe, siły ${ }^{74}$ kształtujące strukturę świata, prowadzi do idei głoszącej „prostotę początku”.

Jest to oczywiście także i metodologiczny oraz epistemologiczny postulat dążenia do prostoty, który w tym kontekście wydaje się jak najbardziej zasadny.

To sprawia, że Laplace ${ }^{75}$ tworzy spójną (metodologicznie, epistemologicznie oraz ontologicznie) strukturę, na którą składają się: świat zjawisk i opisujący je zbiór praw nimi rządzących oraz siły, od których te prawa zależą. A to wszystko zostaje ujęte analitycznie (geometrycznie).

\footnotetext{
${ }^{70}$ Laplace, Historyia astronomii, 108-109.

71 Tamże, 109-113.

72 Tamże, 109.

73 Wróblewski, Historia, 191.

74 Laplace, Historyia astronomii, 122.

75 Tamże, 121-122.
} 
Pozwalało to na dedukcję nieobserwowalnych zjawisk ${ }^{76,}$ czyli odwołując się do prawa "atrakcyi”, można było wyjaśniać zjawiska, postulując istnienie nieobserwowalnych czynników ${ }^{77}$. W konsekwencji zaś uczeni mogli na podstawie obserwowanego stanu układu planetarnego odkryć jego początek $^{78}$, a precyzyjniej - mechanizm jego powstania. Układ oraz funkcjonowanie systemu, na które zwracali uwagę także Descartes i Kant, stosunki między poszczególnymi parametrami ruchu, duże mimośrody komet, a małe planet - to wszystko każe sądzić, że ów układ nie może być efektem przypadku czy też chaosu („hazardu”). Za tę nieprzypadkową strukturę musi odpowiadać jakaś pierwsza, podstawowa przyczyna, obejmująca wszystkie ciała, niezależnie od tego, jak byłyby od siebie oddalone. Przyczyna ta musi zapewniać trwałość systemu. Za owym przekonaniem kryje się także epistemologiczny warunek poznawalności i przewidywalności (powtarzalności) przyrody. W pewnym więc sensie i jej racjonalności (względnej stabilności). Grawitacja („,atrakcya”) jako przyczyna zarówno trwania Układu Słonecznego (a także i Kosmosu), jak i jego struktury zapewnia ową stabilność systemu, mimo że ulega on niewielkim zakłóceniom ${ }^{79}$.

Jakie jest źródło tego przekonania? Otóż, jak twierdzi Laplace, obserwacje mgławic będących $\mathrm{w}$ różnym stopniu ustrukturyzowania pozwalają na wyciągnięcie wniosku, że same gwiazdy i ich systemy mają swoje etapy przejściowe, swoją historię. W tej koncepcji zawiera się idea powstawania, kształtowania, czyli ewolucji struktur wypełniających i tworzących Kosmos. Ów wniosek może także dotyczyć Układu Słonecznego, mającego już jakąś „,skończoną postać”.

Ale $\mathrm{w}$ tym miejscu możemy zadać następujące pytanie: skoro stan układu w danym momencie jest przejściowy, to czy także obecny stan jest również tymczasowy? Czy w takim razie istnieje (i jest możliwy) jakiś stan docelowy, ostateczny? Odpowiedź brzmi: tak. Dzięki sile grawitacji, która stabilizuje i optymalizuje ów układ oraz sprawia, że jest on (a wraz z nim cała natura) układem samoregulującym się ${ }^{80}$. Jednakże co to znaczy, że jakiś stan/układ uzyskał już formę ostateczną lub optymalną? Co o tym decyduje? Czy proces kształtowania się, formowania może mieć jakiś kres, jakieś „ukoronowanie”?

Laplace stwierdza, że ten "filozoficzny widok" wydaje się prawdziwy i pozwala na wniosek, że obecnie obserwowane "obłoczki” staną się kiedyś gwiazdami, a także że widziane dziś gwiazdy musiały być kiedyś

76 Tamże, por. 123 oraz 133-134. Odkrycia z czasów Laplace'a i Herchela potwierdzają heurystyczną wartość teorii grawitacji.

77 Tamże, 123.

78 Tamże, 122.

79 Tamże, 125-126.

80 Tamże, 133-134. 
„materią mglistą" ${ }^{81}$. Idea Laplace'a ujmująca całościowo zjawiska, wraz z ich historią i fizykalnym wyjaśnieniem, jest nowocześnie filozoficznym poglądem na przyrodę. Nawet jeśli uwzględnimy wspomniane już pewne nieśmiałe sugestie (domniemania) Descartes'a o możliwościach zmian w dziejach Kosmosu, to w dziele Laplace'a dostrzegamy jednoznacznie sformułowaną i uargumentowaną teorię kosmologiczną. Czy tej wizji dynamicznej, zmiennej przyrody nie możemy ekstrapolować poza świat zjawisk i obiektów kosmicznych? Skutki siły ciężkości geometrycznie opisane (wywiedzione) potwierdzają to, co można naocznie stwierdzić, obserwując ową harmonię przyrody na Ziemi. Przypływy i odpływy, pory roku, wahania temperatury są mniej lub bardziej bezpośrednio zależne od siły ciężkości. A zatem - można byłoby użyć współczesnego określenia - życie na Ziemi i jego trwałość są uzależnione od kosmicznej siły: grawitacji ${ }^{82}$.

\section{Metafizyka w badaniach przyrody - wybór czy konieczność?}

Poszukując wzajemnych wpływów zasad metafizycznych i matematycznych, a w mniejszym stopniu empirycznych, starałem się ukazać, jak one wzajemnie się przeplatają i przenikają. Analizując wybrane wątki prac czterech wybitnych uczonych XVII i XVIII wieku, którzy w swoich badaniach odwoływali się do fundamentalnie odmiennych założeń, odnosi się wrażenie, że próba separacji owych zasad jest niemożliwa i sztuczna.

Sądzę, iż owe wątpliwości wynikają z kilku podstawowych kwestii.

Otóż jeżeli uczony unika w swoich badaniach odniesień do Boga (Ducha, Rozumu itp.), to docierając do zagadnień związanych z pytaniem o początki Kosmosu, o pierwotne, fundamentalne siły, „,istotę materii”, dotyka kwestii wykraczających poza empiryczne dane i matematyczne własności przyrody, a więc poza to, co matematyzowalne. Kiedy zaś poszukuje jakiegoś stałego czynnika kształtującego świat natury, nawet gdy jest on jej immanentnym elementem, to owo oczekiwanie niezmienności przyrody jest już jakąś psychologiczna, a nie tylko metodologiczną potrzebą, mimo że taka niezmienność umożliwia przewidywalność i poznawalność przyrody. W tym sensie przyroda staje się racjonalna. W innym wypadku świat byłby chaotyczny, niepewny i prowadzący do autodestrukcji oraz samozniszczenia; byłby niepoznawalny. Poszukując

81 Tamże, por. także 121.

${ }^{82}$ Tamże, 128-129. Owa zmienność, ale i zarazem dążność do stabilnych struktur, wpływa stabilizująco na ziemską przyrodę, zapewniając jej harmonię oraz trwanie gatunków. 
źródeł owej niezmienności, nawet jeśli nie jest ona zakorzeniona we własnościach Boga, uczeni wkraczają na grunt metafizyki. Być może jedynym antidotum na tę sytuację jest powiązanie stałości przyrody z niezmiennością (apriorycznością) matematycznych zasad. Ale wówczas można stwierdzić, że owej, z założenia racjonalnej dyscyplinie, zostaje nadany jakiś pozaracjonalny pierwiastek. Czyż myślenie o przyrodzie w kategoriach zasad nie jest zarazem myśleniem metafizycznym i matematycznym?

Skąd zatem pojawiła się oczekiwanie separacji metafizyki (metafizycznych założeń) i zmatematyzowanego przyrodoznawstwa (filozofii przyrody)? Diagnozując też sytuację, Burtt ${ }^{83}$ stwierdza, że odejście (czy też próby rezygnacji) od dotychczasowego metafizycznego oglądu świata przyrody wynikało ze zmiany perspektywy na relację człowieka ze środowiskiem. Trudno nie zgodzić się z jego poglądem, gdy pisze, że starożytny i średniowieczny (dodałbym przy tym, że szczególnie renesansowy) ogląd Kosmosu (ale także i ziemskiej przyrody), narzucający mu własną miarę i sytuujący człowieka jako istotę rozumną w wyjątkowym miejscu, uzasadniał odwoływanie się do rozumu. Zauważmy, że zarówno zasady matematyczne (co wydaje się oczywiste), jak i metafizyczne musiały być zgodne z rozumem. Dla Descartes'a "zgodne z rozumem" było odwoływanie się do własności Boga (które również nie przeczyło rozumowi) w celu poznania własności ruchu i sił (a ogólniej przyrody). Można zatem powiedzieć, że Kosmos został tak zaprojektowany przez Boga, by mógł być ujęty przez ludzki rozum ${ }^{84}$. Innymi słowy - jak podkreśla Burtt - grecka metafizyka znalazła swoje źródło w tym, że zostały rozszerzone na „sferę fizyczną te idee i metody, które wykorzystywano do (badania) indywidualnych i społecznych sytuacji" 85 .

Burtt twierdzi dalej, że możliwa jest i taka przyczyna, iż owe zmiany zaszły dzięki przeformułowaniu (zastąpieniu) funkcjonujących pojęć, takich jak: "substancja”, "materia i forma”, "potencja i aktualność", na ",siły”, ,ruch" i „prawa”. Tak pisze Burtt: „Przestrzenne i czasowe związki były przypadkowymi, nie zaś podstawowymi własnościami. Zamiast przestrzennych powiązań rzeczy ludzie poszukiwali ich logicznych związków; zamiast nieprzerwanego przepływu czasu, ludzie myśleli o wiecznym przechodzeniu od potencjalności do rzeczywistości"86. Tak

${ }^{83}$ Burtt, The Metaphysical. Dziękuję dr Joannie Kaczmarskiej za pomoc w pracy nad tekstem Burtta.

${ }^{84}$ Dziś raczej powiedzielibyśmy, że to ludzki rozum wedle własnej miary konstruuje sobie obraz świata, buduje jego reprezentację. Można byłoby powiedzieć, że wracamy do poprzedniego stanu - podmiot znów kreuje otaczający go świat, staje się "miarą wszechrzeczy”. Różnica polega na tym, że jeśli nawet tak jest, to ma on tego świadomość.

${ }^{85}$ Burtt, The Metaphysical, ok. 26.

86 Tamże. 
więc pojęcia, które wcześniej były niejasne i jakościowe, nie mogły być matematycznie ujęte. Przytaczane w niniejszym artykule takie określenia jak „ukryte jakości” ilustrują ów problem. Historia i filozofia nauki jak sądzę - uzmysławiaja, że reinterpretacja podstawowych pojęć ma zasadnicze znaczenie dla procesu powstania i kształtowania nowożytnej nauki. Widzimy, jak najwybitniejsi uczeni tego okresu, począwszy od Galileusza, przez Boyle’a, na Newtonie skończywszy, swoje badania wiążą ze zmianą wcześniejszego rozumienia funkcjonujących pojęć, w ostateczności nawet rugując je z nauki.

Nieco dalej Burtt zwraca uwagę na jeszcze inny aspekt tego proce$\mathrm{su}^{87}$. Pisze, że przewaga (użyteczność) pojęć matematycznych polega na tym, iż są one jednoznacznie zdefiniowane. Pozbywając się niejasności w rozumieniu pojęć, uczeni sprawiają że sama nauka przestaje być obszarem generującym niejasności i wieloznaczności (co miałoby stanowić istotną własność metafizyki). W tym kontekście powiązanie z matematyką mogłoby uchronić przed zarzutem metafizyczności nawet takie "zabiegi", jak "projektowanie" świata obiektów, zjawisk (bytów) niedostrzegalnych. Są one bowiem wynikiem matematycznych dedukcji, wnioskowań z matematycznych zasad lub obserwacji, a nie efektem spekulacji bez związku z przyrodą czy też matematyką. Nie przynależą już więc do „dziedziny” metafizyki.

Reasumując, można zadać następujące pytanie: na jakie problemy trafiamy, gdy próbujemy diagnozować związki zasad metafizyki, matematyki i empirii oraz płynące z nich konsekwencje, odwołując się do badań Descartes'a, Newtona, Kanta i Laplace'a? Kartezjańskie zasady metafizyki są nie mniej racjonalne (rozumowe) niż zasady matematyki Newtona. Tym bardziej że odwoływanie się do Boga jest oczywiste dla obu uczonych. „Matematycyzm” Newtona tym różni się od "matematycyzmu" Descartes'a (według Gilsona), że Newton nie odwołuje się bezpośrednio do Stwórcy: między Bogiem a przyrodą istnieją naturalne mechanizmy, ujęte w matematycznych formułach. Dla Kanta Bóg jest również „ukryty” za zmatematyzowanymi prawami przyrody (opartymi na empirii), a więc za matematycznymi zasadami. Ale Bóg jest „niezbędny" tylko dlatego, by opisując i wyjaśniając zjawiska fizycznego świata, nie generować w nim sprzeczności. Laplace zaś wiąże przekonanie o heurystycznej wartości matematyki z historią astronomii. Dla tego uczonego matematyka jest , językiem natury" o tyle, o ile może go sprawdzić fizyka ${ }^{88}$.

87 Tamże, 32-33.

${ }^{88}$ Wróblewski, Historia, 191. 


\section{Zakończenie - kilka uwag końcowych}

Można zapytać, czy treści Biblii i Elementów Euklidesa są świadectwami immanentnie tkwiącej w ludzkim umyśle dychotomii w pojmowaniu otaczającej go przyrody; sprzeczności, które wzmacniają doświadczane przez pokolenia zmiany w jej postrzeganiu i w postrzeganiu zmian miejsca człowieka w naturze; zmiany wywołanej przez rozwój wiedzy i technologii, skutkującej coraz rozleglejszą kontrola, czy też panowaniem nad przyroda, przynajmniej w mniemaniu niektórych ludzi. Czy też te dwa dzieła przyczyniają się do generowania owej dychotomii w pojmowaniu i konceptualizowaniu natury? Czy są one źródłem, czy efektem owego rozdwojenia w postrzeganiu (recepcji) zjawisk przyrodniczych? Rozdwojenia charakterystycznego dla cywilizacji zachodniej i być może wyjątkowego w dziejach myśli ludzkiej.

Niezależnie od tego to, co dzieli te dwie perspektywy recepcji świata, jednocześnie łączy je i może stanowić także jakąś formę „,jedności doświadczenia", dążenia do ujęcia zjawisk przyrodniczych oraz samego człowieka w perspektywie ich historii (dziejów), zmian, ewolucji itd. Człowiek więc spisuje historię własnego rodzaju, narodu, plemienia, spisuje historię otaczającego go świata. Owe historie były "mitami”, "historią Biblijną”, „,historią cudów”. Pojawia się jednak także alternatywny sposób narracji o dziejach przyrody i człowieka, w której przyjmuje się również historyczną perspektywę. Ów sposób wymaga jakiejś korelacji między rozumem a zmysłami. Rola obserwacji (a następnie eksperymentów) skłania do przekonania, że owe historie "opowiada" sama przyroda. A zatem w tej narracji rekonstruuje się dzieje przyrody, a wyprowadzone z obserwacji fakty porządkuje rozum. Pojawia się wówczas idea "historii naturalnych" czy też "filozofii przyrody”. W ramach tej samej perspektywy (historycznej) następuje radykalna zmiana w podejściu do treści. Sprawia ona, że czyni się zadość euklidesowej racjonalności. To zaś umożliwia matematyzację przyrody, a jej poznanie wiąże tylko z zasadami matematycznymi.

Jednakże, parafrazując Alfreda Whiteheada, można byłoby na zakończenie powiedzieć: bez metafizycznych założeń nie mogłaby zaistnieć nowożytna i współczesna nauka ${ }^{89}$.

89 Whitehead pisze: „Bez metafizycznych założeń nie mogłaby zaistnieć cywilizacja” (155). Zważywszy, że ma na myśli cywilizację Zachodu, można powiedzieć, że „nie mogłaby zaistnieć” także i wiedza naukowa. Por. Whitehead, Przygody idei. 


\section{Bibliografia}

Bad Hersz. 1931. Geneza i zmierzch legendy Kant-Laplace. Lwów: Wydawnictwo Księgarni M.H. Rubina. Przedruk w: Studia z Historii Filozofii 3, 2 (2015): 46-76.

Boyle Robert. 1661. The Scepical Chymist (wersja polska: przet. Ryszard Krauze, współpraca Zbigniew Pietrzak i Małgorzata Lubańska - w przygotowaniu).

Burtt Edwin A. 1926. The Metaphysical Foundations of Modern Physical Science. New York: Doubleday.

Descartes René. 2010. Medytacje o pierwszej filozofii, przeł. Maria i Kazimierz Ajdukiewiczowie, Zarzuty uczonych mężów wraz z odpowiedziami autora, przeł. Stefan Swieżawski. T. 1. Warszawa: PWN.

Descartes René. 1981. Rozprawa o metodzie, przeł. Wanda Wojciechowska. Warszawa: PWN.

Descartes René. 2005. Świat albo traktat o świetle, przeł. Tomasz Śliwiński. Kraków: Aureus.

Descartes René. 2001. Zasady filozofii, przeł. Izydora Dąmbska. Kęty: ANTYK.

Drozdowicz Zbigniew. 2014. Kartezjański racjonalizm. Poznań: Wydawnictwo Fundacji Humaniora.

Feser Edward. 2019. Aristotle's Revenge. The Metaphysical Foundations of Physical and Biological Science. Neunkirchen-Seelscheid: Editiones Scholasticae.

Garber Daniel. 1992. Descartes' Metaphysical Physics. Chicago, London: The University of Chicago Press.

Galilei Galileo. 1930. Rozmowy i dowodzenia matematyczne w zakresie dwóch nowych umiejętności dotyczacych mechaniki i ruchów miejscowych, przeł. F. K. Warszawa: Wydaw. Kasy im. Mianowskiego Instytutu Popierania Nauki.

Gilson Etienne. 2001. Jedność doświadczenia filozoficznego, przeł. Zofia Wrzeszcz. Warszawa: Altaya de Agostini.

Guicciardini Niccolo. 2011. Isaac Newton on Mathematical Certainty and Method. Cambridge: MA: MIT Press.

Hall Aleksander R. 1966. Rewolucja naukowa 1500-1800, przeł. Tadeusz Zembrzuski. Warszawa: PAX.

Herschel John F. W. 1955. Wstęp do badań przyrodniczych, przeł. T. Pawłowski. Warszawa: PWN.

Kant Immanuel. 2012. Metafizyczne podstawy przyrodoznawstwa. W: Immanuel Kant, Dzieła zebrane. T. 3, przeł. Tomasz Kupś et al., red. Tomasz Kupś, 223-311. Toruń: Wydawnictwo Naukowe Uniwersytetu Mikołaja Kopernika.

Kant Immanuel. 2010. Powszechna historia naturalna i teoria nieba albo szkic o uktadzie oraz mechanicznym pochodzeniu catości świata opracowany zgodnie z prawami Newtona (Allgemeine Naturgeschichte und Theorie des Hommels, oder Versuch von der Verfassung und dem mechanischen Ursprunge des ganzen Weltgebaudes nach Newtonischen Grunsätzen abgebandelt, 1755). W: Im- 
manuel Kant. Dzieła zebrane. T. 1, przeł. Mirosław Żelazny et al., red. Marek Jankowski, Tomasz Kupś, 195-324. Toruń: Wydawnictwo Naukowe Uniwersytetu Mikołaja Kopernika.

Koyré Aleksander. 1998. Od zamkniętego świata do nieskończonego wszechświata, przeł. Ola i Wojciech Kubińscy. Gdańsk: Biblioteka Filozofii i Historii Filozofii.

Laplace Pierre S. 1824. Expositiondu Systeme du Monde Expositiondu Systeme du Monde. Paris: Bachelier.

Laplace Pierre S. 1825. Historyia astronomii krótko zebrana przez markiza de Laplace, przeł. Wincenty Karczewski. Wilno: Drukarnia A. Marcinowskiego.

Lamarck Jean B. 1960. Filozofia zoologii, przeł. Krystyna Zaćwilichowska. Warszawa: PWN.

Lovejoy Arthur O. 2009. Wielki łańcuch bytu. Studium historii pewnej idei, przeł. Artur Przybysławski. Gdańsk: słowo/obraz terytoria.

Newman Wiliam R. 2019. Newton the Alchemist: Science, Enigma, and the Quest for Nature's "Secret Fire". Princeton \& Oxford: Princeton University Press.

Newton Izaak. 2011. Matematyczne zasady filozofii przyrody, przeł. Jarosław Wawrzycki. Kraków: Copernicus Center Press.

Newton Izaak. 1959. Notatki z zakresu alchemii, przeł. Janusz Sytnik-Czetwertyński. Tekst źródłowy w: Isaac Newton The correspondence of Isaac Newton. Vol. 3 (1688-1694), ed. H. W. Turnbull, 1-35. Cambridge: University Press.

Newton Izaak. 2014. O ciężkości i równowadze cieczy, przeł. Adam Grzeliński. W: Empiryczne podstawy i obrzeża filozofii XVII wieku, red. Adam Grzeliński, Jolanta Żelazna, 193-242. Toruń: Wydawnictwo Naukowe Uniwersytetu Mikołaja Kopernika.

Newton Isaac. 1962. Unpublished Scientific Papers of Isaac Newton. A Selection from the Portsmouth Collection in the University Library, Cambridge Chosen, ed. and transl. A.R. Hall and M.B. Hall. Cambridge: Indiana University, The University Press.

Pask Colin. 2013. Magnificent Principia. New York: Prometheus Books.

Pietrzak Zbigniew. 2012. „O osobliwościach Galileuszowej filozofii matematyzacji nauk przyrodniczych". Lectiones \& Acroases Philosophicae V, 1: 151-175.

Rotter Krzysztof. 1992. „Fizyka Galileusza a Arystotelizm. Przyczynek do roli krytyki w rozwoju wiedzy". Nowa krytyka 2: 31-51.

Szyrwińska Anna. 2014. „Z badań nad filozofią Kanta w kręgu Szkoły Lwowsko-Warszawskiej: Hersz Bad o teorii Kanta-Laplace'a". Studia z Historii Filozofii 3, 5: 145-161.

Tempczyk Michał. 2005. Ontologia świata przyrody. Kraków: Universitas.

Whitehead Alfred N. 2020. Przygody idei, przeł. M. Piwowarczyk. Warszawa: PWN.

Wojtysiak Jacek. 2016. „Zasada”. Encyklopedia filozofii przyrody, red. Zenon E. Roskal, 323-344. Lublin: Wydawnictwo KUL. 
Wolter. 2010. Elementy filozofii Newtona, przeł. Helena Konczewska. Warszawa: PWN.

Wróblewski Andrzej K. 2009. Historia fizyki. Warszawa: PWN.

\section{Streszczenie}

Badania przyrodnicze, a szerzej - formułowane wizje otaczającej przyrody, zawsze opierają się na fundamentalnych zasadach (założeniach, aksjomatach, przesłankach itp.). Zasady te mogą być metafizyczne (teologiczne), matematyczne lub empiryczne. $W$ niniejszym artykule, na przykładzie wybranych aspektów dorobku czterech wybitnych filozofów i przyrodników - René Descartes'a, Izaaka Newtona, Immanuela Kanta oraz Pierre'a Simona de Laplace'a, chcę zwrócić uwagę na konsekwencje płynące z przyjęcia różnych zasad. Konsekwencje dla proponowanych koncepcji/teorii przyrody. Ale także na pewne paradoksy związane z tym, że pomimo przyjęcia odmiennych zasad uczeni dochodzą do podobnie brzmiących wniosków oraz że odwoływanie się do tych samych zasad może prowadzić do odmiennych twierdzeń. A co najistotniejsze, to fakt, że zarówno owe podobieństwa, jak i różnice są niekiedy pozorne i zwodnicze.

Słowa kluczowe: Descartes, Izaak Newton, Immanuel Kant, Pierre Simon de Laplace, metafizyka, matematyka, geometria, ruch, siła, grawitacja, materia

\section{On the Diversity of Principles: Philosophical, Mathematical, and Empirical, Underlying Modern Natural Science}

\section{Summary}

The scientific study of nature and, more broadly, formulated visions of nature are always based on fundamental principles (assumptions, axioms, premises, etc.). These principles can be metaphysical (theological), mathematical, or empirical. In this article, using the example of selected aspects of the achievements of four outstanding philosophers and naturalists - René Descartes, Isaac Newton, Immanuel Kant and Pierre Simon de Laplace - I would like to draw readers' attention to the consequences of adopting various principles. The consequences are for the proposed concepts/theories of nature. But also some paradoxes related to the fact that, despite the adoption of different principles, scholars come to similar-sounding conclusions and that applying to the same principles may lead 
to different statements. Most importantly, both these similarities and differences are sometimes apparent and deceptive.

Keywords: René Descartes, Isaac Newton, Immanuel Kant, Pierre Simon de Laplace, metaphysics, mathematic, geometry, movement, force, gravitation, matter 